症例

後腹膜気腫を呈した子宮留膿腫穿孔による汎発性腹膜炎の 1 例

\author{
津和野共存病院外科, 島根医科大学第 1 外科* \\ 平原典幸渡部広明仁尾義 則*
}

症例は76歳，女性。上腹部の劇痛を主訴にショック状態で救急搬送された。来院時白 血球 $14,100 / \mu 1, \mathrm{CRP} 16.77 \mathrm{mg} / \mathrm{dl}$ と炎症反応の上昇を認めた。腹部単純 X線検査にて free air は認めないものの, CT 検査にて右腎臟背側に気腫を認め, 骨盤腔内に比較的均 一な液状物とガスを伴った腫大した子宮と腹水を認めた．腹水は黄色で混濁しており， 便臭ではないものの, 悪臭であった. 子宮留膿腫の破裂による汎発性腹膜炎では free air を呈することが多く，本症例ては後腹膜気腫を認めていたため上部消化管透視にて消化 管穿孔を否定した後, 緊急手術を施行した。開腹時, 子宮底部が破裂しており，混濁し た腹水は腹腔内全体に認めた．子宮は膿が排出されすでに虚脱していた，以上より，単 純子宮全摘術および両側付属器切除術を施行した.これまで約70例の子宮留膿腫の破裂 の報告があるが後腹膜気腫を呈した症例は本症例が初めてであるため報告する。

索引用語：子宮留膿腫穿孔, 汎発性腹膜炎, 後腹膜気腫

\section{緒言}

子宮留膿腫は子宮頸管の狭窄や閉塞により子宮分泌 物の自然排泄が障害され，細菌感染を併発することに より, 子宮腔内に膿汁が貯留する病態であり, 閉経後 の女性に稀にみられる1．また，子宮破裂は帝王切開 術, 筋腫核出術後や, 陣痛促進剤使用時などの分婏時 または悪性疾患に合併して散見されることがあるが， 子宮留膿腫が穿孔し, 汎発性腹膜炎をきたす症例は非 常に稀である゙2).ささらに穿孔例の多くはfree air を呈 することが多いが, 今回われわれは，後腹膜気腫をき たした子宮留膿腫の穿孔例という非常に稀な 1 例を経 験したので報告する.

\section{症例}

患者：76歳，女性.

主訴：上腹部痛.

既往歴: 平成11年, 虫垂切除術.

家族歴：特記すべきことなし。

現病歴：1月 1 日朝, 急に上腹部痛を自覚し, 全く 改善傾向無く, 増悪するため当院に救急搬送された.

入院時現症：身長 $145 \mathrm{~cm}$, 体重 $36.5 \mathrm{~kg}$, 血圧 $66 / 34$

2001年 9 月17日受付 2001年12月12日採用

〈所属施設住所〉

干699-5604 島根県鹿足郡津和野町森村口 141
$\mathrm{mmHg}$, 脈拍 $94 /$ 分・整, 体温 $34.4^{\circ} \mathrm{C}$ とショック状態で あった。顔貌は苦閔状, 蒼白, 痛みのため興奋状態で あった。腹部は軽度膨隆し，板状硬を呈し，自発痛は 上腹部を中心に認めるものの, 圧痛および筋性防御は 腹部全体に認め大. Blumberg 徵候陽性, 腸雑音は著明 に減弱していた。内診では少量の白色帯下を諗めたが 性器出血は認めなかった。

入院時検查所見：白血球 $14,100 / \mu \mathrm{l}, \mathrm{CRP} 16.77 \mathrm{mg} /$ $\mathrm{dl}$ と炎症反応の上昇を認め, 赤血球 $306 \times 10^{4} / \mu \mathrm{l}, \mathrm{Hb}$ $8.6 \mathrm{~g} / \mathrm{dl}, \mathrm{Ht} 26.2 \%$ と貧血を認めた。動脈血ガス分析は $\mathrm{PaO}_{2} 76 \mathrm{mmHg}, \mathrm{PaCo}_{2} 32 \mathrm{mmHg}$, B.E. $-6 \mathrm{mmol} / \mathrm{l}$, と代謝性アシドーシスを呈し，呼吸性に代偩していた。 血液生化学検查は BUN $27.9 \mathrm{mg} / \mathrm{dl}$, Crea $1.18 \mathrm{mg} / \mathrm{dl}$ と腎機能障害は認めたが，その他の検査には異常を認 めなかった.

腹部単純 $\mathrm{X}$ 線検查 : 腹腔内遊離ガス像は認めない ものの, 腸管麻瘏による拡張した小腸ガス像を認め, 右側腹部に孤立した円形のガス像を認めた（図 1 ）。

超音波検查所見：腹部エコーにて少量の腹水と, 渞 下部正中に内部に比較的均一な低から等エコー領域を 伴った腫大した子宮を認め, 子宮留膿腫の診断を得た

(図 2 ).

上部消化管透視：胃，十二指腸および上部消化管に は穿孔を認めず，腹部単純 X線検査にて右側腹部に認 


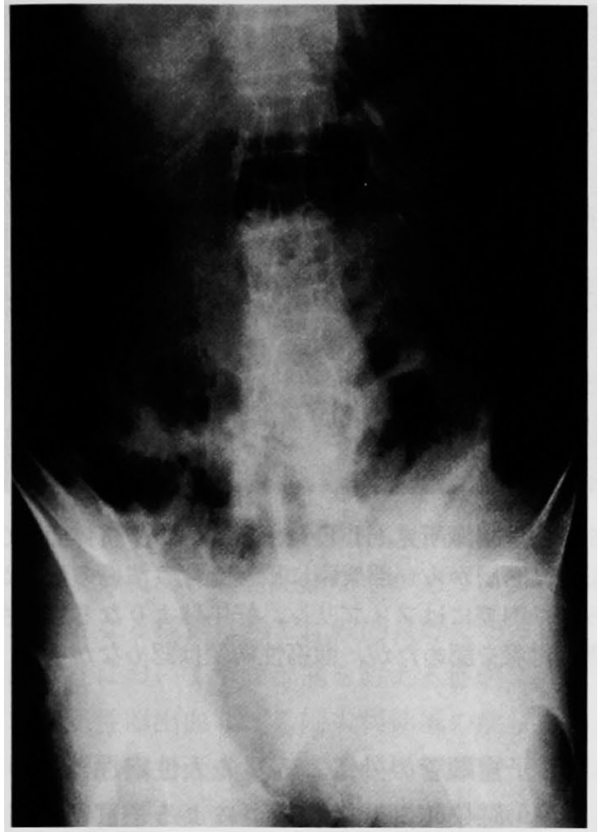

図 1 腹部単純 $\mathrm{X}$ 線検査：拡張した小腸ガス像 を認め，右側腹部に孤立した円形のガス像を 認めた。

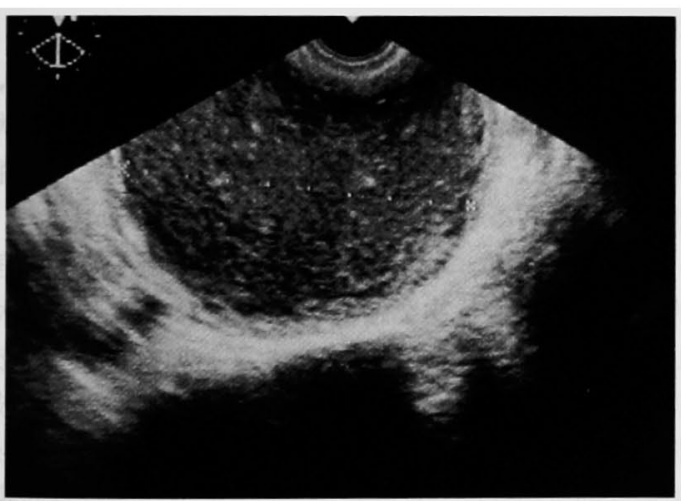

図 2 腹部超音波検査所見：少量の腹水と,臍下部正中 に内部に比較的均一な低から等エコー領域を伴った腫 大した子宮を認めた。

めていた孤立した円形のガス像は十二指腸球部でも大 腸ガスでもないことが判明した（図 3 ）。

腹部 CT 検査所見：右腎葴背側に気腫を認め（図 4 A)，骨盤腔内に比較的均一な液状物とガスを伴った腫 大した子宮を認め，周囲には腹水の貯留を伴っていた (図 4 B).

腹水穿刺：腹水は黄色で混濁しており，便臭ではな

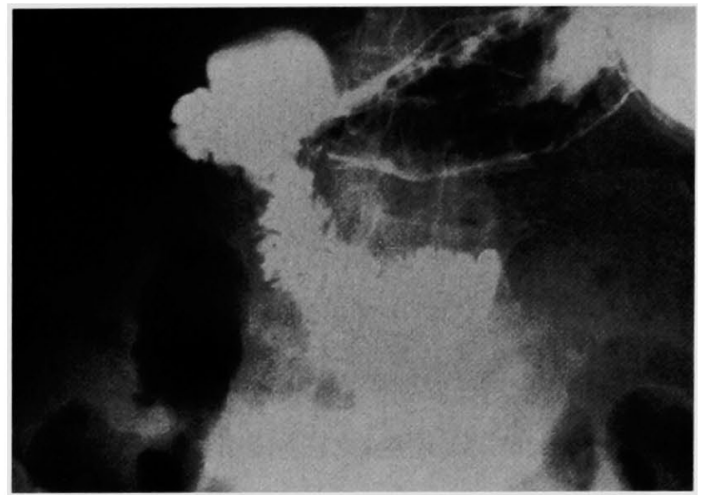

図 3 上部消化管透視：胃, 十二指腸および上部消化管 には穿孔を茨めなかった。
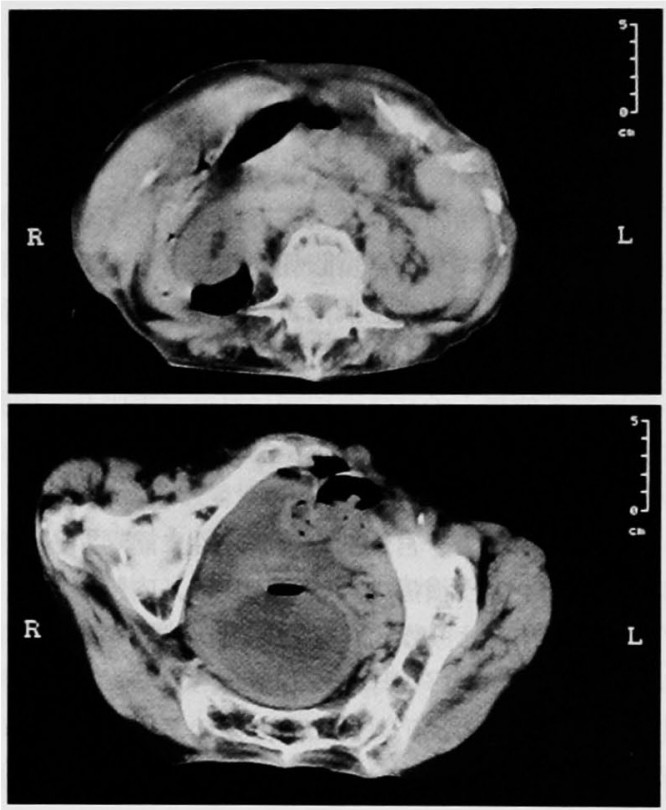

図 4 腹部 CT 検查所見：右腎葴背側に気腫を認め (A)，骨盤腔内に比較的均一な液状物とガスを伴っ た腫大した子宮と腹水を認めた（B）。

$\frac{\mathrm{A}}{\mathrm{B}}$

いものの，悪臭であった。

以上の所見より，非常に稀ではあるが free air を呈 さず後腹膜気腫を伴った子宮留膿腫の破裂による汎発 性腹膜炎を疑い緊急手術を施行した。

手術所見：混濁した黄色の腹水を左右横隔膜下から ダグラス窩まで腹腔内全体に認めた。子宮底部に破裂 部位を認め, 周囲の子宮壁は非常に脆弱化しており, 子宮内に貯留していた膿は破裂してから数時間経過し 


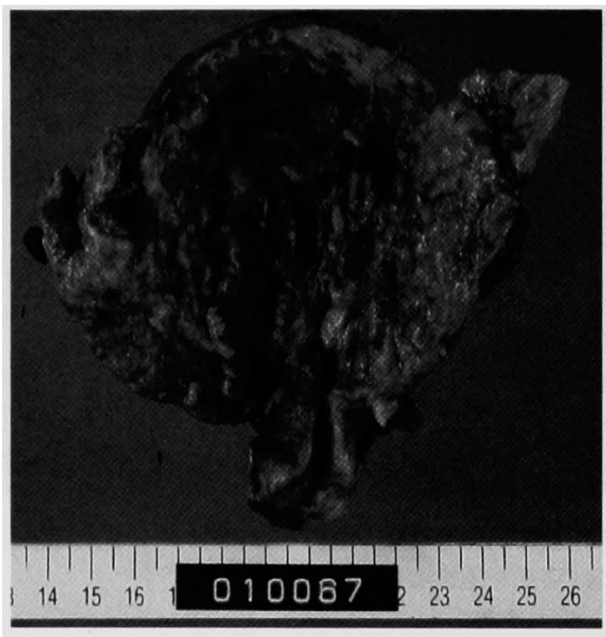

図 5 摘出標本所見：高度に拡張した子宮体部 の内腔には朖が付着し，底部に破裂部位を認め た.

ているため, 腹腔内へほほ全て排出され，子宮は虚脱 していた. 以上より子宮留膿腫穿孔による沉発性腹膜 炎と訬断し, 単純子宮全摘術および両側付属器切除術 を施行した。

摘出標本所見：子宮体部内腔は高度に拡張し，内腔 はびまん性に膿が付着し，不整で底部に破裂部位を認 めた（図 5 ).

病理組織所見：子宮体部はびまん性に筋層から一部 漿膜に破綻を伴う潰瘍の形成がみられ，内县にはフィ ブリン，好中球よりなる炎症性産物の付着を高度に認 めた，筋層内には好中球の浸潤とともにリンパ球，形 質細胞, 組織球の反応は認めるものの, 腫瘍性病変は 認めなかった。以上より, 子宮内膜炎に続発した子宮 留膿腫の破裂と診断した（図6).

術後経過：経過は良好で,術後第40日に退院となった。 考 察

子宮留膿腫は子宮頸管の狭窄や閉塞により子宮腔内 からの分泌物の排泄障害が原因となり，分泌物が子宮 内に貯留し, 子宮留水腫となり, 細菌感染を合併して 膿汁や壊死物質がたまる疾患である”。

好発年齢は40歳以上で, 特に閉経後の女性に多く, 発生頻度は婦人科領域疾患の0.2 0.5\%である ${ }^{234)}$. 原 因としては，1）子宮頸管の狭窄（子宮癌などの悪性 腫瘍，ポリープ，子宮筋腫などの良性腫瘍，老人性頸 管狭窄)，2）悪性腫瘍に対する放射線照射，3) 萎縮 性子宮頸管炎などの子宮頸管の感染，4）人工中絶な

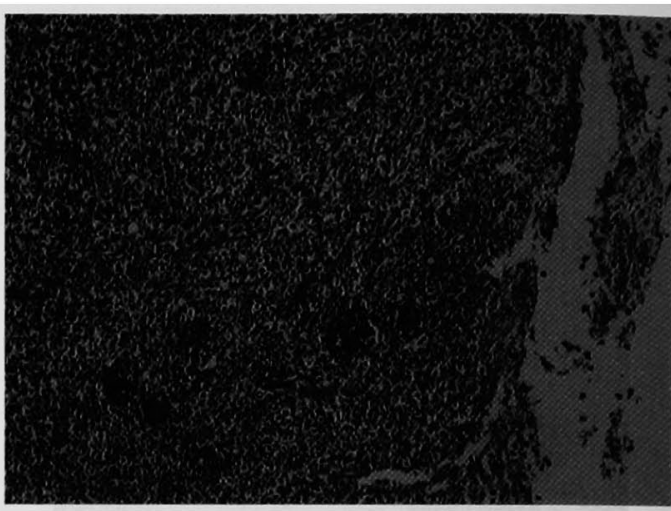

図 6 病理組織所見 $(H . E$ 染色 $\times 100)$ ：子宮体部はびま ん性に筋層から一部槳膜に破綻を伴う潰瘍の形成がみ られ，内腔にはフィプリン，好中球よりなる炎症性産 物の付着を認めたが，腫瘍性病変は認めなかった。

どによる子宮頸管の外傷，5）先天性内性器奇形など があるが，感染防御機構の低下による子宮留膿腫は広 域スペクトラムの抗生剤の進歩により頻度は低下して きている(2)35)6). 起炎菌としては E. coli 以外のグラム 陰性桿菌ちよび嫌気性菌である Bacteroidesなどが多 いが，嫌気性桿菌は婦人科領域では宿主の常在菌とし て外陰部, 臸に存在しているといわれている7!。

子宮留膿腫の症状は膿性帯下, 性器出血, 下腹部痛, 発熱，腫大した子宮の触知などが主であるが，無症状 のまま経過し，本症例のように子宮破裂をきたし急性 腹症として初めて発覚することもある ${ }^{8}$.

診断には，CT，エコーが有用で腫大した子宮と子宮 内に貯留した液状物を確め ${ }^{910)}$ ，内診にて球形に腫大 し，圧痛を有する子宮を触知し，子宮口より悪臭のあ る膿性帯下の排出を想めれば診断は可能である6). 破 裂部位としては子宮底部が多いが，子宮底部以外でも 脆弱な部位が存在すれば破裂部位となり，汎発性腹膜 炎と同様，腹部全体もしくは下腹部を中心とした激し い痛み, 腹部膨满感, 腹膜刺激症状, さらにはショッ ク症状を呈することもある(111).

しかし，子宮留膿腫の破裂は決して診断は容易では ない，術前の正診率は約 $20 \%$ 程度であり，レントゲン 検査上 free air を呈した症例は約30\%，麻痷性イレウ ス像を呈した症例が約30\%であり，これまで約70例の 子宮留膿腫の破裂の症例報告があるが後腹膜気腫を呈 した症例は本症例が初めてである ${ }^{12)}$. Free air を呈し た症例では消化管穿孔による汎発性腹膜炎や急性虫垂 炎の穿孔と診断され手術され，開腹にて初めて診断が 
付くことが多い，本症例ではCTにて腫大した子宮内 に液状物の賍留とガス像を認めたことより子宮留膿腫 穿孔による汎発性腹膜炎を考えた。しかし，遊離ガス 像は呈しておらず，右腎臟背側徭腹膜にガス像を認め たことより十二指腸の後腹膜への穿孔も考え, ガスト ログラフィンにて消化管透視を行い，上腹部消化管穿 孔を否定した後，手術を行った。しかし，開腹時すで に子宮はほほ全ての膿場が排出された後で虚脱してお り, 発症からの時間経過によっても画像診断にて腫大 した子宮を描出できない可能性があり，早期の診断を 要すると思われる.

破裂例の手術としては子宮全摘, 胵上部切断術もし くは子宮壁穿孔部の縫合閉鎖などがあり，予後は敗血 症, DIC となる症例は稀で比較的良好である ${ }^{13)}$.

老齢女性において下腹部痛を訴える症例に対しては 帯下, 不正性器出血などの婦人科領域の症状も常に念 頭においた診療を心がけることが早期䛦断，早期治療 につながると考えられた。

\section{結 語}

後腹膜気腫を呈した子宮留朖腫穿孔による沉発性腹 膜炎の1例を経験したので報告した。

\section{文献}

1) Clarke J: Quoted by Hyndman and Storer. Am J Med Sci $21: 327,1851$

2) Dodge JM:Pyometra. J Arkansas Med Soc $63: 152-156,1966$

3) Henriksen E : Pyometra associated with benign lesions of the cervix and the corpus. West $\mathbf{J}$ Surg $60: 305-321,1952$
4) Whiteley PF, Hamlett JD: Pyometra-reappraisal. Am J Obstet Gynecol 109:108-112, 1971

5）岩崎正惠，森川 肇，東條伸平：老人に発生する 子宮留膿腫，とくに子宮留膿腫穿孔の検討. 産婦 の世界 31 (増刊) : 62-63，1979

6）相良祐輔, 前田長正：婦人科救急疾患とその治療. 7. 子宮留膿腫．産婦治療 $66 ： 667-670,1993$

7) Muram D, Drouin P, Thompson FE, et al: Pyometra. Can Med Assoc J 125:589-592, 1981

8）杉山 宏, 渡部 裕, 安田憲生他：腹腔内破裂を 来した子宮留脓腫の 1 例。消外 $12: 982-986$, 1992

9）高田孝好, 酒井哲也, 多田康之他：子宮留朖腫穿 孔による汎発性腹膜炎の 2 例. 日臨外医会誌 $54: 2682-2686,1993$

10）井筒 岳, 佐藤幸宏, 橋本雅史他：子宫留膿症穿 孔による汎発性腹膜炎の 5 例。日臨外医会誌 $56: 1955-1958,1995$

11）岡本哲也，福嶋久夫，鈴木勝一地：多量の遊離ガ スを発生した子宮留膿腫破裂の 1 治験例。外科 $50: 1037-1039,1988$

12）小野利夫, 阿部博昭, 山下三郎他：子宮留膿腫穿 孔に上る沉発性腹膜炎の 3 症例. 日農村医会誌 $49: 631-636,2000$

13）宮本康二, 山本哲也, 清水幸雄他: 子宮留滕腫破

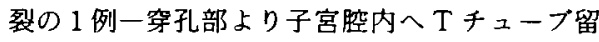
置を施行した例一。手術 $51 ： 1423-1426 ， 1997$ 


\title{
A CASE OF PANPERITONITIS DUE TO SPONTANEOUS RUPTURE OF PYOMETRA WITH RETROPERITONEAL EMPHYSEMA
}

\author{
Noriyuki HIRAHARA, Hiroaki WATANABE and Yoshinori NIO* \\ Department of Surgery, Tsuwano Kyozon Hospital \\ *First Department of Surgery, Shimane Medical University
}

A 76-year-old woman complaining of acute upper abdominal pain was brought into the hospital by ambulance in a shock state. On admission, white blood cell count was $14,100 / \mu 1$ and CRP was $16.77 \mathrm{mg} /$ $\mathrm{dl}$, revealing increased inflammatory responses. Abdominal plain X-ray examination revealed no free air. Abdominal CT scan, however, visualized emphysema on the dorsal aspect of the right kidney, the swollen uterus with comparatively homogeneous fluid and gas, and ascites. The ascites was yellow in color and cloudy. It did not have fecal odor but obnoxious odor. It is known that panperitonitis due to rupture of pyometra often presents with free air. In this case, since we confirmed retroperitoneal emphysema, an emergency operation was performed after an upper gastrointestinal study ruled out a possibility of perforation of the Gl tract. Upon laparotomy, the uterine fundus had ruptured and cloudy ascites was noted in the entire abdominal cavity. The uterine had already prolapsed because pus was exuded from it. Simple total hysterectomy and bilateral adenoxectomy were performed. Although there are reports of 70 cases of a rupture of pyometra, this is the first case of a ruptured pyometra with retroperitoneal emphysema. 